\title{
Informational and constitutional framework for ensuring the accuracy of environmental information disclosure
}

\author{
Valeriya Bulanova *, Olga Petrovskaya \\ Institute of state and law of the Russian Academy of Sciences, Information Law and International \\ Information Security Sector, Moscow 119991, Russian Federation
}

\begin{abstract}
This article is dedicated to the study of the issue of ensuring the accuracy of environmental information disclosure and its informational and constitutional framework. Compliance with the obligatory transparency of environmental information, as well as its accuracy, the need for and reality of observance of informational and constitutional foundations for enforcement of the rights of citizens is the subject of heated discussions. The article makes an emphasis on the nonexistence of a definition for the term "accuracy of information" in the current Russian legislation. Due to the tightening of responsibility for the dissemination of fake information on the Internet, the problem of the definition of "the accuracy of environmental information" takes on special significance. The author calls attention to the facts of untimely disclosure of information about a number of environmental disasters and to the need for improvement of information and legal mechanisms.
\end{abstract}

\section{Introduction}

The modern information society constantly runs into the issue of the accuracy of information. The world of fake information becomes a reality and it is often impossible to understand where we are told the truth, and where there are false stories. The issue of ensuring the accuracy of information disclosure, as evidenced from the research is not irrelevant. The obligation to disclose environmental information is set out in Art. 42 of the Constitution of the Russian Federation and Art. 10 of the Federal Law "Concerning the Protection of the Environment". However, today there are actual instances of noncompliance with the timely disclosure of such information to the public. For example, the diesel fuel spill, which caused the environmental disaster in Norilsk in May 2020, did irreparable damage to nature and sparked a special public outcry due to the timing of delivery of information about this case. Information about the accident first appeared on the Internet and only a few days later came to the notice of the federal authorities.

\footnotetext{
${ }^{*}$ Corresponding author: valeriya777@gmail.com
} 


\section{Research methodology}

The research used scientific methods such as dialectical, logical, historical, predictive, system-oriented analysis, content analysis, as well as specific scientific methods, such as comparative law method and legal modelling method.

All these methods will enable to effectively implement the purpose of the research - to identify the main points of concern of the informational and constitutional framework for ensuring the accuracy of environmental information disclosure.

\section{Results and discussion}

The right to information is certainly one of the fundamental human rights. This follows from the category of intrinsic rights, among which the main ones are the right to life and the right to liberty. These rights are set forth in Art. 19 of the Universal Declaration of Human Rights, proclaimed and adopted on December 10, 1948 by the UN General Assembly. These rights form the basis of the Constitution of the Russian Federation. The main law of the Russian Federation contains a number of norms governing the right of citizens to the accessibility of information, including the disclosure of mechanisms for the exercise of these rights. For example, part 2 of Article 24 of the Constitution of the Russian Federation specifies requirements for state and local government bodies, as well as for their officials to provide every citizen with the opportunity to get acquainted with documents and decrees that directly or indirectly affect their rights and freedoms. In accordance with Article 29 of the Constitution of the Russian Federation, the right to access to information is an undeniable right of the person and of the citizen. Art. 41 specifies the responsibility of persons holding positions of responsibility in the event of concealment of facts and circumstances, as a result of which the life and health of a person could be at risk. In addition, Art. 42 secures the right of citizens to a favorable environment, as well as the right to receive accurate information about its condition.

Consequently, access to environmental information is a guarantee and prerequisite for the exercise of other constitutional rights of citizens - the right to a healthy environment, compensation for damage to health or property caused by an environmental crime, and the right to health protection. At the same time, the poor state of the environment, confirmed by official data, necessitates protection of these rights by the government as well as other human and civil rights and freedoms, embodied in the constitution [1].

In accordance with Art. 3 of the Federal Law No. 7-FZ of January 10, 2002 "Concerning the Protection of the Environment", government authorities and municipalities are responsible for ensuring a favorable environment, as well as environmental safety in the territories under their jurisdiction. The said law also secures the right of everyone to receive accurate information about the state of the environment and the right of citizens to participate in adoption of decisions about their rights to a healthy environment. These rights can be exercised by citizens (legal entities) by making inquiries at the state and local government bodies, as well as at other organizations about the state of the environment in their places of residence and measures taken to protect it.

The Federal Law No. 174-FZ, dated November 23, 1995 "Concerning Ecological Examinations" specifies that the mechanism of legal regulation provided for therein is a means for enforcement of the constitutional right of citizens of the Russian Federation, which concerns a favorable environment. Art. 6 of this Law contains a norm according to which the state authorities of the constituent entities of the Russian Federation are responsible for provision of accurate and full information to the public about the planned and current environmental impact assessments and the results of the relevant expert examinations. Art. 9 specifies a regulatory provision, which relates to the provision of 
information to the federal executive authorities about the environmental impact assessment in respect of the anticipated business activity of a corresponding municipality. In addition, it is necessary to provide information to the prosecutor's office about the beginning of the implementation of environmental impact assessment pending a specific conclusion from the Federal Environmental Expertise Office. Article 19 provides for the obligations according to which the state expert commission on environmental impact assessment is obliged to make decisions on the implementation of the task order with an eye to public opinion. It should be admitted, however, that in actual practice the public often has no information about the forthcoming state environmental appraisal of particular facilities [2].

Concealment or falsification of environmental information constitutes grounds for administrative liability in accordance with Art. 8.5 of the Administrative Offences Code of the Russian Federation.

It is noteworthy that Article 237 (Chapter 25) of the Criminal Code of the Russian Federation also contains grounds for the onset of criminal liability for hiding of information, including information about circumstances that are threatening the life or health of people. At the same time, it is emphasized that according to the formal criteria, Art. 237 of the Criminal Code of the Russian Federation has no relevance to Chapter 26 "Environmental Crimes". However, if we consider that the commission of the act specified therein afflicts harm to the life or health of people or the environment, the crime may refer to the environmental crimes [3].

The accuracy of information is very important in the modern information society. In the enormous flow of existing data the information is not always correct. In the absence of criteria for determining the correctness of information, there is likelihood of violation of the right to accurate information, which will result in wrong decisions. Active discussions are underway in many countries about the legal regulation of the criteria for the accuracy of information. On the one hand, legal regulation and compliance with these criteria should not violate the right of man to express personal opinion, on the other hand (and this is particularly important for government bodies), the disclosed official information should be carefully checked, and not only from a factual point of view, but also in terms of conflict with current legislative aspects. The risks are high, because the existence of any conflict at the legislative level is fraught with a deterioration of confidence in government bodies [4].

It should be noted that the need to guarantee access to environmental information to the extent of the enforcement of the constitutional right of citizens to accurate information about the state of the environment is determined not only by internal reasons, but also by a number of external circumstances. In particular, the issue of accession of Russia to the Convention of the UN Economic Commission for Europe, which deals with access to information, remains still unresolved. 38 states ratified this convention in the Danish city of Aarhus in 1998 (the so-called Aarhus Convention). Although the representatives of the Russian Federation took an active part in the discussion of issues related therewith, Russia has not ratified this important international document.

Exploration of the issue of free access to environmental information began 8 years earlier, after the Council of the EU on June 7, 1990 adopted a Directive 90/313 / EEC, which was entitled "On free access to environmental information". This directive specified the degree of accessibility of environmental information in written, visual, acoustic or factual form. It was understood that this information included information about the state of waters, air environment, soil, flora and fauna, natural resources, as well as activities or actions that cause damage (including actions that cause environmental nuisances such as constant noise), affect (or may adversely affect ) the environment, or actions and measures related to environmental protection, including administrative measures and environmental programs. It is noteworthy that this definition does not take into account information on climate change and conditions of human life as a result of environmental disasters or other 
calamities. The issue of access to environmental information was actively discussed in 1995 at the conference of the ministers of the environment of European countries in Sofia, which the Russian side attended as well. Following the results of this conference, guidelines were approved for ensuring access to environmental information and participation of the public in adoption of environmental solutions.

The prospects for the ratification of the decisions of the Aarhus Convention by Russia are assessed differently. In particular, Professor S.A. Bogolyubov believes that the convention is not yet in effect on the territory of the Russian Federation due to the unpreparedness of the Russian law enforcement agencies, as well as nonexistence of appropriate information systems. At the same time, in his opinion, although the adoption of the provisions of this convention is not mandatory as applied to this country, they can serve as a guideline for the enforcement of requirements regarding the disclosure of environmental information to citizens. In a number of regulatory enactments there are regulatory provisions for information support to the areas of activity, which can and should be considered in the round in the performance by the authorities of environmental protection measures and in the enforcement of the right of everyone to accurate information about the state of the environment [5].

Comparison of the current Russian legislation and the provisions of the Aarhus Convention attests to the fact that, on the one hand, Russia has the possibility of unhindered accession to the Convention, and on the other hand, there is a need to amend and supplement certain legislative enactments in the field of the environment, environmental administration, as well as to adopt new federal laws.

In this context, account should be taken of the public opinion in making decisions and for the purposes of access to justice in environmental matters. One of the fundamental provisions of the Aarhus Convention, which will certainly be discussed in the context of the accession of Russia, is the authorization of access to environmental information. This requires the legislative recognition of the concept and composition of this information, as well as the establishment of the procedure for its disclosure to citizens, public organizations, for its exchange between state and local authorities and for the legal solution of other problems. There is no concept of environmental information in the Russian legislation, however, a significant number of federal laws on the environment, sanitary and epidemiological standards and other issues contain legal regulatory provisions aimed at protecting the rights of citizens, public organizations and ensuring the rule of law on receipt of certain information related to the environment. All these measures are implemented within the context of the right of every citizen, embodied in Part 4 of art. 29 of the Constitution of the Russian Federation, to accurate information about the state of the environment (the right to free search, receipt, transfer, development and dissemination of information permitted by the legislation of the Russian Federation) [6].

The issue of ratification of the Aarhus Convention is very urgent. Successful implementation of economic and social reforms, as well as solution of environmental problems, depends on the regulation and establishment in the Russian Federation of the principles of true supremacy of law, which is based on democratic principles. It must be noted that public involvement in decision-making processes, ensuring transparency of information, ability to resort to judicial authorities for protection of own rights, obtaining competent legal assistance - all these conditions are among the crucial components of any society in which the supremacy of law is declared. For a long time almost all the environmental information has been beyond the reach of the public. The authorities had the sole right for disclosure and storage of this information.

The Aarhus Convention "On Access to Information, Public Participation in DecisionMaking and Access to Justice in Environmental Matters" was enacted on October 30, 2001. As previously noted, the Russian Federation did not sign it. It turns out that in Russia there 
is no clear model of legal regulation in respect of the environmental information. A disappointing result of this is the absence of systematization of the Russian legislation in this matter, as well as the extremely unsystematic and illogical use of the term "environmental information".

In addition to understanding the legal regime of environmental information and ensuring easiness of access to it, it is very important to resolve other problems. Among them, one can single out such as setting the deadlines for the disclosure of environmental information in general and specific information on a particular issue. For example, Art. 12 of the Federal Law No. 59-FZ, dated May 2, 2006 "On the procedure for consideration of appeals from citizens of the Russian Federation" states that a written application to a government body, local government body or an appeal to an official in accordance with his competence must be considered within 30 days from the date of registration of the written inquiry. In cases provided for by the law, this deadline may be extended for a maximum of 30 days upon a notice to the applicant. This rule applies to all types of information, including environmental information, as regards inquiries made in one form or another. The legislation on environmental protection provides for other, shorter deadlines for the provision of information. Under bylaws of individual organizations, the deadlines for disclosure of information can vary from three to thirty days, and in emergency situations account for one working day, and in some cases - a few hours. Local government bodies also set deadlines shorter than 30 days for their subordinate organizations.

Subject to other administrative regulations, other deadlines may established for the provision of public services by federal executive bodies involving disclosure of various information regarded as environmental. This issue also requires legal regulation as regards specifying a definite deadline for and form of disclosure depending on the nature of the environmental information. In case of failure to meet the established deadlines, the environmental information should be considered outdated. And entities which did not provide it on time should be held liable. In particular, Art. 8.5 of the Administrative Offences Code of the Russian Federation provides for administrative liability for concealment, deliberate distortion or premature disclosure of complete and accurate information about the state of the environment and natural resources, as well as about sources of pollution, sources that caused environmental pollution or other harmful effects on it,or affected the radiation situation, as well as for falsification of information about the state of soil, water and other natural environment locations by persons who are obliged to report such information. At the same time, this article covers only part of the information related to environmental information, and also does not provide for liability for failure to disclose and refusal to disclose this information. Conversely, in real life, such cases are very common.

The first important step in the history of the lawmaking of the Russian Federation concerning the concept of "information" and the disclosure of the principles of its accuracy was the enactment of the Federal Law No. 149-FZ, dated July 27, 2006 "On Information, Information Technologies and Information Protection". This law sets forth the key terms in the field of information relations and establishes the principles for regulation of relations in this area [7]. One of the key principles is the principle of accuracy of information and timeliness of its disclosure.

The Decree of the President of the Russian Federation No. 203, published on May 9, 2017 "Concerning the strategy for the development of the information society in the Russian Federation for 2017-2030" establishes the right and the need for storage, processing, creation and dissemination of accurate information. To create an information space based on the knowledge-driven economy, the need was introduced to guarantee the human right to objective and accurate information. This right creates conditions that guarantee satisfaction of the needs of citizens in ongoing development, obtaining accurate 
information, acquiring new competencies through a safety system that ensures the accuracy of the data received [8].

At the same time, despite the relevant regulatory provisions, no direct legislative definition or criteria of "information accuracy" have been officially enshrined. Today, from the standpoint of enforcement and protection of the right to information, both in general and in relation to environmental information, it is necessary to determine the content of the principle of information accuracy, assign clear criteria for its definition, in order to understand in which cases correctness and accuracy is extremely important, and where situations are allowed enabling to identify the source of inaccurate information.

It is noteworthy that the requirements for the value of accurate information are important both at the level of individual households and at the level of the government, especially when it comes to compliance with the norms of the law. For this reason, a particularly careful study of the concept of "accuracy of information" is required as well as an understanding of its nature, clear assessment criteria and enforcement principles [9].

It should be noted that a systematic work is being underway in the Russian Federation on the placement of information available to government agencies in the format of open databases. However, there is still a problem with the information that needs to be published and the frequency of its updating.

One of the key problems in ensuring the accuracy of information is the problem of cybersecurity in the course of dissemination of accurate environmental information [10-12].

Another burning issue is the disclosure of complete, correct and accurate information on the Internet. As a rule, what is posted on the Internet is information about approved state bodies and officials, texts of regulatory enactments, plans and results of surveys at natural resources protected sites. At the same time, international experience shows the need to include in the databases more complete and accurate information: information on licenses of companies for certain types of activities, trustworthy results of tolerability and risks of their activities, daily environmental monitoring data [13].

Despite the fact that Russian legislation has accorded the citizens the right to receive information about the state of the environment, the concept of "environmental information" has not yet been defined, just like the concept of and criteria for accuracy of environmental information, requirements for accuracy in a particular case, its parameters and criteria.

\section{Consclusions}

The analysis of the current legislation shows that a number of processes related to the collection, accumulation, and dissemination of environmental information have been resolved in Russia. However, due to a high level of environmental and legal nihilism of the population, citizens have only a general idea of environmental problems. Unfortunately, the issues involving provision of access to environmental information, as well as to its individual forms, have not been resolved in terms of special treatment. No criteria for the accuracy of environmental information have been defined. All this makes the exercise of the right to receive environmental information problematic and does not allow to exercise other constitutional rights as far as is necessary, including the right to a favorable environment.

This research was financially supported by the State Task No. 0136-2021-0042 «Legal regulation of the digital economy, artificial intelligence, and information security». 


\section{References}

1. L.K. Tereshchenko, Modernization of information relations and information legislation. (Institute of Legislation and Comparative Law under the Government of the Russian Federation, INFRA-M, Moscow, 2015)

2. I.S. Barzilova, Problems of Economics and Legal Practice, 3, 116 - 121 (2019)

3. O.V. Teslya, Yong Scientist, 3(62), 110 -113 (2014)

4. E.V. Ustyuzhanina, Electronic appendix to the "Russian law magazine", 4(42), 47 - 52 (2017)

5. S.A. Bogolyubov, Environmental law, 3, 2 -11 (2013)

6. R.V. Amelin, Izvestia of the Saratov University. New series. Economics series. Management. Law., 7(4), 458 - 467 (2017) ..

7. Federal Law No. 149-FZ, dated July 27, 2006 "Concerning Information, Information Technologies and Information Protection"

8. T.A. Polyakova, A.V. Minbaleev, V.B. Naumov, Works of the Institute of State and Law of the Russian Academy of Sciences, 13(5), 194 -208 (2018) ..

9. T.A. Polyakova, A.V. Minbaleev, N.V. Krotkova, State and Law, 5, 75 -87 (2020)

10. K. Y. Nikolskaya, S. A. Ivanov, V. A. Golodov, A. V. Minbaleev and G. D. Asyaev, International Conference "Quality Management,Transport and Information Security, Information Technologies" (IT\&QM\&IS), 87-89 (St. Petersburg, 2017)

11. I. Kaftannikov, V. Zhernova, A.V. Minbaleev, Proceedings of the 1st International Scientific Conference "Modern Management Trends and the Digital Economy: from Regional Development to Global Economic Growth" (MTDE 2019), 73-79 (2019)

12. T.A. Polyakova, A.V. Minbaleev, I.S. Boychenko, Bulletin of the Academy of Law and Management, 3 (52), 32 -36 (2018)

13. S.V. Simonova, Pressing problems of Russian law, 15(11), 172 -179 (2020) 